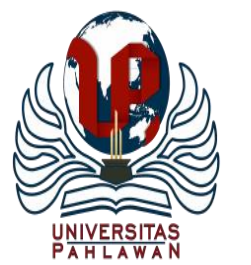

Edukatif : Jurnal Ilmu Pendidikan Volume 3 Nomor 4 Tahun 2021 Halm 1699 - 1707

EDUKATIF: JURNAL ILMU PENDIDIKAN

Research \& Learning in Education

https://edukatif.org/index.php/edukatif/index

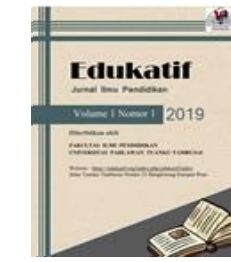

\title{
Peningkatan Prestasi Belajar Siswa dengan Menerapkan Kecerdasan Emosional dan Dukungan Sosial pada Siswa SMA
}

\author{
Mujidin $^{1 凶}$, Ajeng Rizky Ardhia Pramesti², Husnul Khotimah Rustam ${ }^{3}$ \\ Universitas Ahmad Dahlan, Indonesia ${ }^{1,3}$ \\ Universitas Ahmad Dahlan, Indonesia ${ }^{2}$ \\ E-mail : mujidin.230760@gmail.com ${ }^{1}$, ajengpramesti28@gmail.com ${ }^{2}, \underline{\text { husnulkhotimahr6@ gmail.com }}^{3}$
}

\begin{abstract}
Abstrak
Dukungan sosial dan kecerdasan emosional menjadi penggerak siswa dalam belajar. Tujuan penelitian ini adalah untuk mengetahui pengaruh dukungan sosial dan kecerdasan emosional terhadap prestasi belajar pada siswa kelas XI. Sampel yang digunakan adalah siswa-siswi kelas XI SMA Negeri 1 Bengkulu Selatan. Jumlah responden sebanyak 78 orang. Kami mengumpulkannya dengan teknik cluster random sampling. Diuji dengan analisis regresi berganda dua prediktor. Hasil penelitian menunjukkan ada pengaruh signifikan dukungan sosial dan kecerdasan emosional terhadap prestasi belajar siswa. Kecerdasan emosional dengan nilai signifikan 0,013 yang berarti semakin tinggi kecerdasan emosional maka semakin tinggi pula prestasi belajar. Siswa memiliki manajemen emosi dan motivasi yang kuat sehingga mampu beradaptasi dengan baik walaupun dengan situasi yang membosankan, mengantuk, sulit, dan tidak mudah diprediksi. Kecerdasan emosional memberi dampak positif sekaligus mendukung siswa untuk memperhatikan nilai sekolah maupun perangkat lainnya yang berkaitan dengan sekolah. Penelitian ini sudah membuktikan adanya pengaruh kecerdasan emosional, meskipun dukungan sosial tidak signifikan. Hasil penelitian ini diharapkan sebagai evaluasi terhadap kualitas belajar siswa dan tentunya dukungan sosial dapat tercapai.
\end{abstract}

Kata Kunci: dukungan sosial. Kecerdasan emosional, prestasi belajar, motivasi.

\section{Abstract}

Social support and emotional intelligence become the driving force of students in learning. The purpose of this study was to determine the effect of social support and emotional intelligence on learning achievement in class XI students. The samples used were students of class XI SMA Negeri 1 Bengkulu Selatan. The number of respondents as many as 78 people. We collected them by cluster random sampling technique. Tested by multiple regression analysis of two predictors. The results showed that there was a significant effect of social support and emotional intelligence on student achievement. Emotional intelligence with a significant value of 0.013 which means the higher the emotional intelligence, the higher the learning achievement. Students have strong emotional management and motivation so that they are able to adapt well even in situations that are boring, sleepy, difficult, and not easy to predict. Emotional intelligence has a positive impact as well as supports students to pay attention to school grades and other devices related to school. This study has proven the influence of emotional intelligence, although social support is not significant. The results of this study are expected to be an evaluation of the quality of student learning and of course social support can be achieved.

Keywords: social support, emotional intelligence, learning achievement, motivation.

Copyright (c) 2021 Mujidin, Ajeng Rizky Ardhia Pramesti, Husnul Khotimah Rustam

$\triangle$ Corresponding author

Email : mujidin.230760@gmail.com

DOI $\quad$ : https://doi.org/10.31004/edukatif.v3i4.644

ISSN 2656-8063 (Media Cetak)

ISSN 2656-8071 (Media Online) 
1700 Peningkatan Prestasi Belajar Siswa dengan Menerapkan Kecerdasan Emosional dan Dukungan Sosial pada Siswa SMA - Mujidin, Ajeng Rizky Ardhia Pramesti, Husnul Khotimah Rustam

DOI: https://doi.org/10.31004/edukatif.v3i4.644

\section{PENDAHULUAN}

Siswa memiliki hak dan kewajiban di sekolah. Pada umumnya, siswa dituntut untuk memperoleh prestasi belajar yang memuaskan dan memberikan output sehingga mampu mengharumkan nama sekolah di kompetisi nasional maupun internasional. Seperti yang diungkapkan Trisnawati (2013) melalui pendidikan di sekolah, setiap siswa dapat mengembangkan kemampuan intelektual dan karakter yang baik. Implementasi intelektual ini merujuk pada evaluasi guru terhadap hasil belajar siswa melalui raport. Hasil belajar berupa deretan angka yang menggambarkan sejauh mana pengaruh ilmu diserapnya selama satu semester kemudian ditafsirkan. Lembaga pendidikan wajib menindaklanjuti hasil belajar siswa. Siswa terkondisikan dengan berbagai latihan, lalu mengikuti proses pembelajaran dan terakhir menampakkan perubahan penampilan (Wahyudi \& Neviyarni, 2021). Perubahan tersebut bisa dari aspek mana saja, namun salah satu yang ditekankan oleh sekolah adalah aspek prestasi belajar. Indikator prestasi belajar diacu pada standar nilai yang ditetapkan masing-masing sekolah dan perubahan prestasi setiap siswa meningkat dari tahun ke tahun pada semua mata pelajaran (Riswanto \& Aryani, 2017). Guru sangat berperan penting untuk melihat secara objektif kemampuan belajar siswa.

Idealnya siswa yang telah melalui proses pembelajaran akan mengalami peningkatan prestasi belajar. Dengan kata lain, individu mendapatkan hasil yang memuaskan. Namun, masih banyak ditemukan kurangnya situasi ideal tersebut. Berdasarkan studi awal Supratno, dkk (2021) siswa kelas V belum mampu mengoptimalkan prestasi belajar mereka dengan baik. Kebanyakan, prestasi siswa tidak merata ada yang sangat baik, baik cukup bahkan ada yang kurang (Supratno, dkk 2021). Prestasi belajar dapat ditingkatkan dengan berbagai cara, namun satu-satunya cara ampuh yakni dengan belajar dan mempelajari banyak hal. Individu membutuhkan konsentrasi penuh untuk belajar agar ilmu yang diserapnya dapat diingat sepanjang waktu. Prestasi belajar perlu ditingkatkan.

Belajar dilakukan dengan mengulangi kembali materi belajar yang diberikan sebelumnya. Individu mengupayakan usahanya maksimal sehingga ilmu pengetahuan yang didapatkan bisa dipahami dengan baik. Individu mencari tahu hal yang tidak dimengerti kemudian ditanyakan pada guru. Setelah menerima informasi, individu belajar mengolah kembali informasi tersebut hingga menguasai materi pembelajaran dari guru. Pada dasarnya, belajar dilakukan untuk mendapatkan konsep yang matang sehingga mampu berinteraksi dengan dunia pendidikan (Suarim \& Neviyarni, 2021). Setelah konsep yang ditanamkan guru sudah matang, maka guru tidak boleh berpuas diri. Guru masih memiliki tugas utama lainnya untuk kepentingan siswa. Guru tetap mengawal proses siswa hingga menyelesaikan studi di sekolah tersebut. Di setiap semester, siswa menerima rapor. Rapor ini bertujuan untuk memaparkan pancapaian akademik dan non akademik siswa selama satu semester. Alat ini juga sebagai media evaluasi pembelajaran guru terhadap kualitas peserta didiknya.

Belajar dengan intensitas yang cukup tinggi sangat membantu siswa untuk mencapai prestasi akademik. Namun, bukan hanya dari intensitas masih ada faktor-faktor lainnya yang memicu prestasi. Peran kecerdasan emosional sangatlah penting, dari hasil penelitian Mavroveli dan Sánchez-Ruiz (2011) bahwa individu yang memiliki kecerdasan emosional maka akan lebih banyak memusatkan perhatian dan berusaha menenangkan diri dengan tugas-tugas akademiknya di sekolah. Kecerdasan emosional mengandung nilai positif yang sangat berpengaruh pada peningkatan prestasi siswa sebab individu memiliki motivasi (Budi, 2010). Kecerdasan emosional membawa individu pada sikap empati dan peka terhadap lingkungan. Individu sangat mudah mengontrol emosinya sehingga dapat berinteraksi dengan orang lain (Pinar, dkk 2017). Mengontrol emosi memudahkan siswa berfokus pada tujuannya yakni ingin berprestasi di sekolah. Individu menyiapkan diri menjadi lebih tenang saat mendapatkan soal yang sulit, tidak menangis, tidak mengeluh, lebih kritis dan lain sebagainya. 
1701 Peningkatan Prestasi Belajar Siswa dengan Menerapkan Kecerdasan Emosional dan Dukungan Sosial pada Siswa SMA - Mujidin, Ajeng Rizky Ardhia Pramesti, Husnul Khotimah Rustam

DOI: https://doi.org/10.31004/edukatif.v3i4.644

Individu harus siap mempelajari segala hal di luar kendalinya. Salah satu faktor pendukung yang mengendalikan siswa adalah lingkungan sosial. Lingkungan sosial menemani langkah siswa baik itu dalam proses belajar, bertumbuh dan lain sebagainya. Mereka adalah sekumpulan orang yang harusnya memberi dukungan satu sama lain. Dukungan sosial memprediksi hasil belajar yang lebih baik. Ada motivasi, empati, moral, finansial dan bentuk dukungan sosial lainnya yang memungkinkan perubahan perilaku dan kognitif siswa. Individu mampu bertahan dan menguatkan diri dalam situasi yang kurang menyenangkan. Dukungan inilah yang berkolaborasi dengan motivasi internal siswa sehingga menghasilkan prestasi belajar yang signifikan. Internal maupun motivasi eksternal dapat berdampak pada psikologis siswa. Siswa punya keinginan atau tekad yang kuat untuk melayani dirinya. Individu terus berkembang selama masa sekolahnya. Individu terpapar dengan berbagai dukungan sosial dan berupaya menyeimbangkannya dengan kecerdasan emosional yang tinggi.

Penelitian-penelitian terdahulu menunjukkan prestasi belajar dapat meningkat sebab ada faktor yang sangat mendukung, seperti pada Wiyono dkk (2019), Efendi, (2016), Kusrini dan Prihartanti (2014). Pertama, hasil penelitian menunjukkan perhatian orangtua, motivasi belajar, dan lingkungan sosial secara bersamasama memberikan pengaruh yang singnifikan terhadap prestasi belajar matematika siswa SMP dengan sumbangan sebesar $10,6 \%$. Secara parsial perhatian orangtua dan motivasi belajar memberikan pengaruh terhadap prestasi belajar sementara lingkungan sosial tidak memberikan pengaruh terhadap prestasi belajar. Perbedaannya adalah pada penelitian ini menggunakan kecerdasan emosional dan dukungan belajar pada siswa SMA. Kedua, berpikir kreatif mampu mempengaruhi prestasi belajar mahasiswa sebesar 23\%. Penelitian ini lebih berfokus pada remaja yang bersekolah di SMA. Ketiga, kepercayaan diri mampu memprediksi remaja untuk lebih berprestasi. Kemudian, pembaruannya adalah variabel yang diteliti dalam penelitian ini mengambil kecerdasan emosional sebagai faktor pendukung prestasi belajar.

Penelitian ini dilakukan dengan memperbarui acuan pembuatan skala yang dimana peneliti membuat skala berdasarkan fenomena yang terjadi saat ini. Kecerdasan emosioanl yang dimaksudkan dalam penelitian ini adalah pengaruh pengelolaan, pengenalan, dan strategi untuk memodifikasi emosi menjadi lebih baik yang dimana penelitian terdahulu tidak membahasnya secara mendalam. Sedangkan, dukungan sosial yang dimaksudkan dalam penelitian ini adalah pengaruh dukungan teman sebaya, orang tua, guru, kepala sekolah, dan keluarga terhadap prestasi belajar siswa yang belum spesifik dibahas pada penelitian terdahulu. Penelitian ini bertujuan untuk menjelaskan hubungan dukungan sosial dan kecerdasan emosional terhadap prestasi belajar siswa. Permasalahan siswa dalam lingkup sekolah sangat kompleks sehingga dibutuhkan kemampuan untuk mengatur dan mengambil kendali atas peristiwa yang terjadi di sekolah. Permasalahan di sekolah terlihat dari banyaknya nilai siswa yang anjlok, tidak memberikan piagam atau piala yang banyak untuk sekolah, jumlah siswa tidak bertambah, dan kurangnya prestasi akademik di sekolah. Kepala bagian kesiswaan SMA Negeri 1 Bengkulu Selatan mengatakan bahwa prestasi belajar di sekolah tersebut mengalami peningkatan tiap semester dan tahunnya walaupun peningkatan prestasi belajar tersebut tidak terlalu besar hanya sebesar 20\% saja. Namun, sejak pandemik Covid-19 ini, prestasi belajar siswa-siswi di sekolah tersebut sedikit mengalami penurunan dan pihak sekolah sudah mencari solusi agar prestasi belajar siswa/siswi di sekolah tersebut meningkat kembali. Temuan Jatira dan S (2021) juga mendapatkan hal yang sama yang dimana belajar siswa sudah tidak efektif, tidak konsentrasi mengerjakan tugas dan merasa lebih banyak beban dari orang-orang di rumah.

Berdasarkan data diatas, terlihat telah terjadinya penurunan prestasi akademik siswa. Akan tetapi permasalahan penurunan prestasi akademik tidak selalu menjadi kesalahan sistem dan kebijakan pihak-pihak yang menaungi saja karena sudah banyak upaya yang dilakukan untuk meningkat kualitas pendidikan di Indonesia walaupun usaha ini masih di rasa belum cukup untuk meningkatkan prestasi atau kualitas siswa. Sehingga, hal tersebut menjadi krusial agar ditemukan penanganan yang mengkhusus untuk meningkatkan prestasi bukan hanya non akademik namun akademiknya juga. Penelitian ini diharapkan dapat memberikan 
1702 Peningkatan Prestasi Belajar Siswa dengan Menerapkan Kecerdasan Emosional dan Dukungan Sosial pada Siswa SMA - Mujidin, Ajeng Rizky Ardhia Pramesti, Husnul Khotimah Rustam

DOI: https://doi.org/10.31004/edukatif.v3i4.644

solusi untuk permasalahan pada siswa SMA agar prestasi belajar siswa dapat meningkat dari waktu ke waktu meskipun banyak tekanan dari pihak sekolah. Maka, berdasarkan latar belakang yang dijabarkan peneliti tertarik untuk membuat suatu penelitian dengan judul "Peningkatan Prestasi Belajar Siswa dengan Menerapkan Kecerdasan Emosional dan Dukungan Sosial pada Siswa kelas XI".

\section{METODE PENELITIAN}

Kuantitatif adalah jenis penelitian yang disematkan dalam penelitian ini. Peneliti membuat skala untuk mengukur sejauh mana kategori dukungan sosial dan kecerdasan emosional pada siswa SMA kelas XI SMA 1 Bengkulu Selatan. Peneliti mendatangi sekolah tersebut dan membawa surat penelitian lalu diserahkan kepada pihak sekolah. Teknik sampelnya adalah cluster random sampling dengan total 78 orang. Skala kecerdasan emosional disusun dari Goleman (2012) yakni mengenali emosi diri, mengelolah emosi, motivasi diri, mengenali emosi orang lain dan keterampilan sosial. Selanjutnya, skala dukungan sosial dibuat berdasarkan aspek-aspek Sarafino (2011) diantaranya dukungan emosional dan penghargaan, dukungan instrumental, informasi dan persahabatan. Reliabilitas Cronbach Alpha pada skala kecerdasan emosional sebesar 0,836. Selanjutnya, skala dukungan sosial besaran Cronbach Alpha sebesar 0,901. Peneliti menggunakan SPSS versi 20.0 untuk mengolah datanya. Peneliti mengumpulkan referensi dari berbagai jurnal dan buku. Untuk menguji hipotesisnya, peneliti menggunakan dua uji yakni uji asumsi dan uji hipotesis. Jika asumsi terpenuhi, maka dapat dilanjutkan ke uji hipotesis.

\section{HASIL DAN PEMBAHASAN PENELITIAN}

Hasil penelitian menunjukkan adanya pengaruh secara simultan antara kecerdasan emosional dan dukungan sosial terhadap prestasi belajar pada siswa SMA Kelas XI SMA N 1 Bengkulu Selatan. Skoring yang dilakukan memberi kategori tertentu pada skala kecerdasan emosional dan skala dukungan sosial.

Tabel 1. Kecerdasan Emosional

\begin{tabular}{cccc}
\hline Interval & Kategori & Frekuensi & Persentase \\
\hline $84,11266 \leq \mathrm{X}$ & Tinggi & 58 & 74,36 \\
\hline $79,46254 \leq \mathrm{X}<84,11266$ & Sedang & 13 & 16,66 \\
\hline $\mathrm{X}<79,46254$ & Rendah & 7 & 8,98 \\
\hline Total & & 78 & $100 \%$ \\
\hline
\end{tabular}

Pada tampilan tabel 1, tujuh siswa yang memiliki level rendah, kemudian lima puluh delapan siswa yang memiliki kecerdasan emosional tingkat tinggi. Hasil ini menunjukkan adanya korelasi dengan kemudahan siswa dalam mengelola emosinya. Tabel selanjutnya adalah dukungan sosial.

Tabel 2. Kategorisasi Dukungan Sosial

\begin{tabular}{cccc}
\hline Interval & Kategori & Frekuensi & Persentase \\
\hline $84,11266 \leq X$ & Tinggi & 0 & 0 \\
\hline $79,46254 \leq X<84,11266$ & Sedang & 5 & $6,41 \%$ \\
\hline$X<79,46254$ & Rendah & 73 & $93,59 \%$ \\
\hline Total & & 78 & $100 \%$ \\
\hline
\end{tabular}

Skor dukungan sosial pada tabel 2 sangat beragam. Mulai dari kategori sedang sebesar 6,41\% dengan frekuensi sebanyak lima orang. Selanjutnya, kategori rendah sebanyak tujuh puluh tiga orang dengan 
1703 Peningkatan Prestasi Belajar Siswa dengan Menerapkan Kecerdasan Emosional dan Dukungan Sosial pada Siswa SMA - Mujidin, Ajeng Rizky Ardhia Pramesti, Husnul Khotimah Rustam

DOI: https://doi.org/10.31004/edukatif.v3i4.644

persentasi 93,59\%. Kategori dukungan sosial hanya rendah hingga sedang. Selanjutnya, pengaruh kecerdasan emosional dan dukungan sosial secara simultan dijelaskan pada tabel di bawah ini

Tabel 3. Analisis Regresi Linier Berganda

\begin{tabular}{ccccc}
\hline Model & $R$ & $R$ Square & $\begin{array}{c}\text { Model Summary } \\
\text { Square } R\end{array}$ & Std. The error of the Estimate \\
\hline 1 & 0,042 & 0,013 & 0,042 & 2,25870 \\
\hline
\end{tabular}

Dari tabel di atas, maka terlihat bahwa nilai R sebesar 0,042 dan R Square sebesar 0,013. Hal tersebut menunjukkan terdapat $13 \%$ pengaruh kecerdasan emosional dan dukungan sosial terhadap prestasi belajar.

Tabel 4. Koefisien regresi masing-masing prediktor

\begin{tabular}{|c|c|c|c|}
\hline & $\mathrm{r}_{\mathrm{xy}}$ & $\mathrm{P}$ & Keterangan \\
\hline $\begin{array}{l}\text { Kecerdasan emosional } * \text { Prestasi } \\
\text { belajar }\end{array}$ & $-0,283$ & 0,013 & Hipotesis diterima \\
\hline $\begin{array}{llll}\begin{array}{l}\text { Dukungan } \\
\text { belajar }\end{array} & \text { sosial } & * & \text { Prestasi } \\
\end{array}$ & 0,212 & 0,064 & Hipotesisi ditolak \\
\hline
\end{tabular}

Tindaklanjut penelitian ini adalah mengolah data menjadi hasil penelitian. Kecerdasan emosional dan dukungan sosial bersama-bersama mempengaruhi prestasi belajar siswa dengan nilai $p 0,013<0,05$. Nilai tersebut sangat jelas membuktikan relevansi pada hipotesis mayor. Selanjutnya secara parsial tidak menunjukkan demikian. Untuk variabel kecerdasan emosional nilai signifikannya sebesar 0,013<0,05. Koefisien regresi dukungan sosial jauh lebih tinggi dari yang seharusnya yakni 0,064 >0,05. Dukungan sosial dinilai tidak berpengaruh terhadap peningkatan prestasi belajar. Nilai rxy kecerdasan emosional terhadap prestasi belajar sebesar 0,283. Nilai ini lebih besar daripada dukungan sosial yang sebesar 0,212.

Model penelitian ini berkaitan dengan korelasi regresi yang hasilnya berkorelasi positif berarti terdapat hubungan yang signifikan antara kecerdasan emosional dan dukungan sosial terhadap prestasi belajar siswa. Maryani dan Widjajanti (2021) dari hasil penelitiannya menegaskan bahwa kecerdasan emosional merupakan faktor penting yang terkait dengan prestasi belajar, khususnya pada bagian emosi internal individu. Nauli Thaib (2013) menambahkan bahwa kecerdasan emosional merupakan faktor penting yang harus dimiliki oleh siswa yang mempunyai kebutuhan untuk mencapai prestasi belajar yang lebih baik di sekolah dan mempersiapkan mereka untuk menghadapi dunia nyata dan disarankan agar sekolah khususnya guru memasukkan unsur kecerdasan emosional dalam menyampaikan materi dan melibatkan emosi siswa dalam proses pembelajaran. Siswa melibatkan diri dalam proses pembelajaran ditambah lagi dengan motivasi. Buktinya, dari hasil penelitian, Pratama, dkk (2019) motivasi menjadi prediktor yang sangat kuat untuk meningkatkan prestasi dan hasil belajar siswa. Siswa asyik dengan metode pembelajaran gurunya dan menyimak dengan baik. Ansong, dkk (2017) menemukan bahwa faktor emosional diterima secara seimbang dalam hipotesis penelitian ini. Keterlibatan emosional bisa dicirikan saat di kelas, saya merasa senang.

Emosi sering terlibat dalam kehidupan, termasuk siswa (Sharma, 2017). Siswa mengedepankan perasaan emosionalnya untuk belajar, ingatan, menentukan keputusan, gaya belajar, sukses di sekolah atau berinteraksi dengan lingkungan sosial (Rai \& Khanal, 2017). Ungkapan ini terlihat jelas dari hasil penelitian Singh, dkk (2013) yang menyatakan bahwa dengan kecerdasan emosional siswa dapat memahami informasi yang relevan dari lingkungannya. Selain pemahaman, siswa yang memiliki kecerdasan emosional tinggi dan tujuan akademik tercapai (Singh, dkk, 2013); (Mursaleen \& Munaf, 2016). Kecerdasan emosional menjadi pegangan yang penting untuk mewujudkan kesuksesan siswa (Bimayu, dkk 2020). Hasil penelitian Bimayu, dkk (2020) menjelaskan bahwa kecerdasan emosi yang baik dan terkendali juga meningkatkan prestasi 
1704 Peningkatan Prestasi Belajar Siswa dengan Menerapkan Kecerdasan Emosional dan Dukungan Sosial pada Siswa SMA - Mujidin, Ajeng Rizky Ardhia Pramesti, Husnul Khotimah Rustam

DOI: https://doi.org/10.31004/edukatif.v3i4.644

belajar, sebaliknya jika kecerdasan emosi buruk dan tidak terkendali maka prestasi belajar siswa juga menurun. Peneliti menemukan bukti kuat tentang fenomena ini berdasarkan hasil penelitian (Jenaabadi, dkk, 2015). Kecerdasan emosional dalam beberapa penelitian dianggap mampu memprediksi prestasi belajar siswa, diantaranya dari peningkatan motivasi akademik (Shibila Sabir|Sannet Thomas, 2020) ; manajemen waktu, mampu mencapai tujuan yang jelas dan berkomunikasi secara tegas dengan orang lain (Koç, 2019).

Dari penelitian ini ditemukan bahwa tidak ada hubungan antara dukungan sosial dengan prestasi belajar. Seharusnya, setiap siswa mendapatkan dukungan sosial namun pada kenyataannya karena pembelajaran secara daring individu mendapatkan banyak gangguan dan kurang dukungan dari keluarga, orang tua, dan guru. Seperti yang diungkapkan (Suriadi et al., 2021), lingkungan yang kurang mendukung menyebabkan penurunan karakter pada siswa misalnya mengucapkan kata-kata yang tidak pantas dalam berkomunikasi dengan guru ataupun anak ke orang tuanya. Dukungan sosial dari guru dan teman sebaya juga berperan penting dalam pencapaian siswa di sekolah. Bagi siswa, guru adalah seseorang yang memiliki kewenangan selain orang tuanya dalam hal pendidikan. Sedangkan peer group merupakan kelompok yang memiliki kedekatan khusus satu sama lain sehingga dapat saling mempengaruhi. Banyak faktor yang menjadi penghambat penurunan prestasi akademik mahasiswa, diantaranya perubahan situasi pembelajaran saat ini melalui internet atau konferensi virtual. Akibatnya, tanpa bimbingan langsung dan tatap muka, siswa dituntut menjadi pembelajar mandiri untuk belajar seperti mengambil sumber dari internet untuk memenuhi tugas sekolah, namun siswa kurang memahami materi (Teeraputon \& Nuankaew, 2020). Konsekuensi yang harus diterima oleh siswa adalah mengikuti pembelajaran secara daring. Berbeda dengan tahun-tahun sebelumnya, pembelajaran seperti ini masih jarang dilakukan. Banyak diantaranya terjadi pembelajaran physical distancing, penggunaan yang cepat dan pasif akibatnya siswa mengalami shock terhadap proses pembelajaran (Suriadi, dkk, 2021). Pihak sekolah diharapkan mampu membangun sistem yang lebih mendukung dan mengembangkan keterampilan-keterampilan terbaru siswa untuk meningkatkan dukungan sosial dari seluruh warga sekolah baik itu teman sebaya hingga personil sekolah. Pihak sekolah diharapkan dapat mendesain pola-pola dukungan sosial yang signifikan untuk membantu siswa mengatasi stress ataupun tekanan serta kesulitan-kesulitan yang dihadapinya.

Dukungan sosial dalam penelitian Cirik (2015) berbanding terbalik dengan hasil penelitian ini yang menjelaskan bahwa dukungan sosial yang diperoleh siswa dari orang tua mereka, guru, dan teman sebaya memiliki pengaruh positif pada prestasi dan motivasi mereka. Temuan ini menunjukkan bahwa persepsi dukungan sosial oleh siswa meningkatkan rasa ingin tahu mereka, mendorong pembelajaran yang bermakna, memastikan, merasa bermanfaat bagi diri mereka yang bertujuan meningkatkan efikasi diri, menurunkan kecemasan ujian mereka, dan meningkatkan tingkat pencapaian mereka. Perbedaan lainnya juga ditemukan dalam penelitian de la Iglesia, dkk (2014) pengaruh dukungan sosial terhadap prestasi akademik. Hal ini dipersepsikan oleh kebanyakan perempuan dalam penelitian de la Iglesia, dkk (2014). Salah satu hasilnya tidak signifikan dipengaruhi beberapa faktor. Sampel penelitian yang terlalu sedikit membuat variansi skor tidak begitu berbeda. Keterbatasan lainnya juga ditemukan sebab menyebarkan skala ini melalui Google Doc sehingga peneliti tidak dapat menjangkau kegiatan yang bisa mempengaruhi jawaban subjek. Ada beberapa faktor yang tidak diteliti lebih spesifik dalam penelitian ini sehingga bisa menjadi bahan pertimbangan untuk peneliti selanjutnya.

Ilmu pengetahuan terus berkembang, harapannya dengan adanya kecerdasan emosional siswa mampu menyikapi perubahan tersebut dengan baik. Perubahan yang serba cepat dan dinamis diharapkan tidak membuat siswa meluapkan emosinya secara brutal atau sembrono. Kecerdasan emosional dapat digunakan dalam kehidupan sehari-hari, dapat memotivasi orang lain utnuk melakukan hal yang sama, mendukung secara emosional orang lain, berempati satu sama lain, membahagiakan diri sendiri sendiri dan orang lain agar tercipta kehidupan yang mendukung, damai dan sejahtera. Saran untuk peneliti selanjutnya, telitilah kecerdasan-kecerdasan lainnya seperti kecerdasan kinestatik, linguistik, dan tujuh kecerdasan lainnya yang 
1705 Peningkatan Prestasi Belajar Siswa dengan Menerapkan Kecerdasan Emosional dan Dukungan Sosial pada Siswa SMA - Mujidin, Ajeng Rizky Ardhia Pramesti, Husnul Khotimah Rustam

DOI: https://doi.org/10.31004/edukatif.v3i4.644

mungkin dapat mempengaruhi prestasi belajar siswa. Diperlukan adanya penelitian lebih lanjut pengaruh kecerdasan emosional dan dukungan sosial terhadap prestasi belajar agar prestasi belajar siswa meningkat. Sekolah perlu dengan cara guru dan orang tua memperhatikan perkembangan emosional siswa dan selalu menciptakan suasana yang nyaman dan gembira agar siswa lebih termotivasi lagi mengejar prestasi belajarnya. Siswa belum menemukan gaya belajar yang tepat sehingga prestasi belajar tidak meningkat. Faktor kepribadian juga bisa menjadi alternatif bahan penelitian. Jika siswa memiliki tekad dan ketekunan, perlahan prestasi belajarnya juga meningkat. Banyak hal yang bisa diteliti untuk meningkatkan prestasi belajar. Individu yang memiliki keterbelakangan mental juga memiliki keunikan tersendiri untuk diteliti. Peneliti selanjutnya diharapkan mampu melewati berbagai tantangan selama proses penelitian.

\section{KESIMPULAN}

Dari pembahasan di atas dapat disimpulkan kecerdasan emosional dan dukungan sosial dapat meningkatkan prestasi belajar siswa. Dalam pengaruh kecerdasan emosional, siswa mampu mengontrol, mengenal, dan membuat strategi dalam memainkan emosinya sehingga dapat beradaptasi di lingkungan. Perkembangan emosional siswa menjadi lebih baik tergantung bagaimana seorang siswa menghadapi berbagai tuntutan dari sekolah. Siswa dapat berkomunikasi menggunakan bahasa yang mudah dimengerti. Namun, ada juga siswa yang kurang mengerti dan mengontrol emosinya sehingga kurang mampu beradaptasi dengan guru maupun teman sebaya. Siswa yang tinggal di lingkungan kurang yang mendukung cenderung kurang menerima dukungan tersebut dan berdampak pada prestasi belajarnya.

\section{UCAPAN TERIMA KASIH}

Kami berterimakasih kepada seluruh pihak yang telah membantu terselesaikannya penelitian ini, pihakpihak yang terkait seperti Universitas Ahmad Dahlan Yogyakarta, Kepala Sekolah SMA Negeri 1 Bengkulu Selatan, siswa-siswi SMA Negeri 1 Bengkulu Selatan dan para responden yang telah memberikan kontribusinya, saran, dukungan material dan non-material. Segala bentuk bantuan sangat berarti demi kelancaran proses penelitian ini. Penelitian ini berdiri secara independen.

\section{DAFTAR PUSTAKA}

Ansong, D., Okumu, M., Bowen, G. L., Walker, A. M., \& Eisensmith, S. R. (2017). The role of parent, classmate, and teacher support in student engagement: Evidence from Ghana. International Journal of Educational Development, 54(May), 51-58. https://doi.org/10.1016/j.ijedudev.2017.03.010

Bimayu, W., Kristiawan, M., \& Fitriani, Y. (2020). The Effect of Emotional Intelligence, Student's Motivation toward Student's Achievement. International Journal of Progressive ..., April, 6-16. http://www.ijpsat.es/index.php/ijpsat/article/view/1708

Budi, B. (2010). Pendidikan karakter. In Informasi (Vol. 1, Issue 100).

Cirik, I. (2015). Relationships between social support, motivation, and science achievement: Structural equation modeling. Anthropologist, 20(1-2), 232-242.

de la Iglesia, G., Stover, J. B., \& Liporace, M. F. (2014). Perceived social support and academic achievement in Argentinean college students. Europe's Journal of Psychology, 10(4), 637-649. https://doi.org/10.5964/ejop.v10i4.777

Efendi, S. H. (2016). Hubungan Antara Berpikir Kreatif dan Dukungan Sosial Dengan Prestasi Belajar Mahasiswa Jurusan Teknik Mesin Fakultas Teknik Universitas Negeri Malang. In Jurnal Pendidikan Profesional (Vol. 5, Issue 3). Universitas Negeri Malang. 
1706 Peningkatan Prestasi Belajar Siswa dengan Menerapkan Kecerdasan Emosional dan Dukungan Sosial pada Siswa SMA - Mujidin, Ajeng Rizky Ardhia Pramesti, Husnul Khotimah Rustam DOI: https://doi.org/10.31004/edukatif.v3i4.644

Jatira, Y., \& S, N. (2021). Fenomena Stress dan Pembiasaan Belajar Daring dimasa Pandemi Covid-19. Edukatif: Jurnal Ilmu Pendidikan, 3(1), 35-43. https://doi.org/10.31004/edukatif.v3i1.187

Jenaabadi, H., Shahidi, R., Elhamifar, A., \& Khademi, H. (2015). Examine the Relationship of Emotional Intelligence and Creativity with Academic Achievement of Second Period High School Students. World Journal of Neuroscience, 5(4), 1-6. https://doi.org/10.4236/wjns.2015.54025

Koç, S. E. (2019). The Relationship between Emotional Intelligence, Self-Directed Learning Readiness and Achievement. International Online Journal of Education and Teaching, 6(3), 672-688.

Kusrini, W., \& Prihartanti, N. (2014). Hubungan Dukungan Sosial dan Keperceyaan Diri dengan Prestasi Bahasa Inggris Siswa Kelas VIII SMP Negeri 6 Boyolali. Jurnal Penelitian Humaniora, 15(2), 131-140.

Maryani, N., \& Widjajanti, D. B. (2021). Comparison of Contextual and Scientific Approaches to Improving Student Achievement and Emotional Intelligence. Proceedings of the 7th International Conference on Research, Implementation, and Education of Mathematics and Sciences (ICRIEMS 2020), 528(Icriems 2020), 368-374. https://doi.org/10.2991/assehr.k.210305.053

Mavroveli, S., \& Sánchez-Ruiz, M. J. (2011). Trait emotional intelligence influences on academic achievement and school behaviour. British Journal of Educational Psychology, 81(1), 112-134. https://doi.org/10.1348/2044-8279.002009

Mursaleen, M., \& Munaf, S. (2016). Associations of Intellectual Ability with Emotional Intelligence, Academic Achievement and Aggression of Adolescents. Journal of Basic \& Applied Sciences, 12(August 2016), 344-350. https://doi.org/10.6000/1927-5129.2016.12.53

Nauli Thaib, E. (2013). Hubungan Antara Prestasi Belajar Dengan Kecerdasan Emosional. Jurnal Ilmiah Didaktika, 13(2), 384-399. https://doi.org/10.22373/jid.v13i2.485

Pinar, S. E., Busra, C., Merve, K., Neslihan, S., \& Feyza, S. (2017). Emotional Intelligence Levels and Cyberbullying Sensibility among Turkish University Students. International Online Journal of Education Science, 9(3), 676=685.

Pratama, F., Firman, \& Neviyarni. (2019). Pengaruh Motivasi Belajar IPA Siswa Terhadap Hasil Belajar. EDUKATIF : Jurnal Ilmu Pendidikan, 280-286. https://edukatif.org/index.php/edukatif/index\%0APENGARUH

Rai, D., \& Khanal, Y. K. (2017). Emotional intelligence and emotional maturity and their relationship with academic achievement of college students in Sikkim. International Journal of Education and Psychological Research ( IJEPR), 6(2), 1-5.

Riswanto, A., \& Aryani, S. (2017). Learning motivation and student achievement : description analysis and relationships both. COUNS-EDU: The International Journal of Counseling and Education, 2(1), 42. https://doi.org/10.23916/002017026010

Sharma, R. (2017). Emotional Intelligence, Social Intelligence and Achievement Motivation of Arts and Science Students. $\square \square \square \square \square \square \square \square \square, 4(3), 57-71$. http://marefateadyan.nashriyat.ir/node/150

Shibila Sabir | Sannet Thomas. (2020). Emotional Intelligence and Achievement Motivation among College Students. International Journal of Trend in Scientific Research and Development, 4(6), 1351-1353. url: https://www.ijtsrd.com/papers/ijtsrd33657.pdf\%0Ahttps://www.ijtsrd.com/humanities-and-thearts/psychology/33657/emotional-intelligence-and-achievement-motivation-among-collegestudents/shibila-sabir

Singh, T., Verma, M. K., \& Singh, R. (2013). Role of Emotional Intelligence in Academic Achievement. 1(2), 255-263. https://doi.org/10.4018/978-1-4666-4530-1.ch016

Suarim, B., \& Neviyarni, N. (2021). Hakikat Belajar Konsep pada Peserta Didik. Edukatif: Jurnal Ilmu Pendidikan, 3(1), 75-83. https://doi.org/10.31004/edukatif.v3i1.214

Supratno, Y. H., Murtono, \& Mochamad, W. (2021). The Influence of Student Motivation, School Environment, on Student Learning Achievement. Journal of Physics: Conference Series, 1823(1). 
1707 Peningkatan Prestasi Belajar Siswa dengan Menerapkan Kecerdasan Emosional dan Dukungan Sosial pada Siswa SMA - Mujidin, Ajeng Rizky Ardhia Pramesti, Husnul Khotimah Rustam

DOI: https://doi.org/10.31004/edukatif.v3i4.644

https://doi.org/10.1088/1742-6596/1823/1/012089

Suriadi, H. J., Firman, F., \& Ahmad, R. (2021). Analisis Problema Pembelajaran Daring Terhadap Pendidikan Karakter Peserta Didik. Edukatif: Jurnal Ilmu Pendidikan, 3(1), 165-173. https://doi.org/10.31004/edukatif.v3i1.251

Teeraputon, D., \& Nuankaew, P. (2020). Attitude and Learning Styles in Different Academic Achievement of Tertiary Students. Universal Journal of Educational Research, 8(11B), 6178-6184.

Trisnawati, destya dwi. (2013). Membangun Disiplin Dan Tanggung Jawab Siswa Sma Khadijah Surabaya melalui tata tertib sekolah. Kajian Moral Dan Kewarganegaraan, 2(1), 397-411. https://jurnalmahasiswa.unesa.ac.id/index.php/jurnal-pendidikan-kewarganegaraa/article/view/2658

Wahyudi, I., \& Neviyarni, N. (2021). Analisis Terhadap Perhatian Dan Belajar Perseptual Dalam Aktivitas Belajar Siswa. Edukatif: Jurnal Ilmu Pendidikan, 3(1), 124-134. https://doi.org/10.31004/edukatif.v3i1.231

Wiyono, A., Anggo, M., \& Kadir, K. (2019). PENGARUH KECERDASAN EMOSIONAL TERHADAP HASIL BELAJAR MATEMATIKA SISWA KELAS VIII MTs NEGERI 1 KENDARI. Jurnal Penelitian Pendidikan Matematika, 6(2), 113. https://doi.org/10.36709/jppm.v6i2.9121 